\title{
French Impressions-The 2014 EACE Annual Meeting
}

\author{
Joseph F. O'Donnell
}

Published online: 25 June 2014

(C) Springer Science+Business Media New York 2014

I had the extraordinary privilege of representing the journal at the 27th annual scientific meeting of the EACE in Caen, France from March 26-28, 2014. This is the third EACE meeting I have attended, and at each, my overwhelming feeling is about the collegiality of the participants. John Sloan Dickey was a previous president at Dartmouth, my institution. He was a global visionary and he used to say to the students that "the world's problems are our problems and there are none that cannot be solved by better people." There were a whole host of these "better people" in Caen putting their energy and creativity together to work on the problem of cancer. It was both humbling and inspiring to me.

The tone for the extraordinary hospitality was set by our hosts, Dr. and Mrs. Jean-Francois Heron and their team from the Centre Francois Baclesse, the state-of-the-art comprehensive cancer center in Caen. They opened their hearts and welcomed us to their beautiful city, the Normandy region, their center and their programs of which they are very proud. The respect for Jean-Francois Heron by his colleagues was palpable. Caen was an amazing host city, full of vitality, history and wonderful messages about the hope for world peace. It was very moving to visit the Museum for the Peace and the Normandy landing beaches, so close in time to the 70th anniversary of the Allied Invasion, an event that changed the world. We all owe so much to those brave young soldiers. Another extraordinary part of this meeting was the food and the spirit of fun with singing and much laughing especially at the celebratory final banquet where we said thank you and goodbye to our hosts and colleagues from all over the world. The feeling of solidarity and learning from each other was pervasive. One of the hidden gems of the meeting program (and a feature of the past programs) and as a special touch put

J. F. O’Donnell ( $\square)$

Geisel School of Medicine at Dartmouth, Hanover, NH, USA

e-mail: Joseph.F.ODonnell@Dartmouth.edu in by EACE President Graham Dark, are a series of inspirational quotes about education sprinkled throughout the booklet. Here's one that caught my eye and I think captured the meeting very well: "To gain the most from your journey, treat every person you meet as teacher and every situation as a learning opportunity." (Eric Attenbaugh). Every person in Caen was a teacher for me.

The EACE is as healthy as I have ever seen it. The scientific program prepared with the conference theme of Educating Everyone for Cancer Care and Palliative Care, and constructed by an expert program team led by Graham Dark, featured wonderful plenary talks, podium presentations, poster presentation, and workshops plus enough time for mingling where I thought a great deal of learning went on. There were presentations from all over Great Britain, Lithuania, Poland, Germany, the Netherlands, Canada, Italy, Austria, Australia, the USA and of course, France. There were presentations from students, virtually every type of health professional dealing with cancer, patients, and even a Baroness, who is a member of Parliament. The presentors showed both tremendous poise and tremendous courage presenting in English which for many was not their native language. The workshop on setting standards in assessment by the cohesive team of Graham Dark and Darren Starmer was very useful and very well received. That and many other presentations would be beautiful, informative pieces in our journal. I also have to give huge kudos to Cancer Surgeon Radoslaw Tarkowski from Wroclaw Medical University in Poland who gave a rousing Milly Haagedoorn lecture about mentorship and inspiring the students coming along to join in the quest to eliminate cancer. He is an amazing role model who will surely inspire many in Poland to follow his path.

We left Caen full of hope, inspiration, and a sense of solidarity in our efforts to "reduce the burden from cancer in the world through effective education" as is the motto of our journal. We also left with memories of great food, great fun, 
and fantastic hosts. Graham Dark in his last official duty as a president (a leader who really made a difference for the EACE and an extremely talented, knowledgeable, and versatile educator himself) turned the gavel over to new President, Darren Starmer, who will surely continue to catalyze the upward momentum of EACE. Next year's meeting will be in the beautiful and historic city of Heidelberg, Germany. My advice to all of you is to put that meeting on your calendars, go experience the amazing collegiality and welcoming hospitality plus the scientific and educational inspiration of an EACE meeting. Dickey was right that "the world's problems are our problems." This group aligned with AACE and CPEN will be a force to help solve these problems, and the JCE will be an important vehicle to disseminate the collective wisdom. 